\title{
Addictive Video Game Use: An Emerging Pediatric Problem?
}

\section{Dependência de Vídeojogos: Um Problema Pediátrico Emergente?}

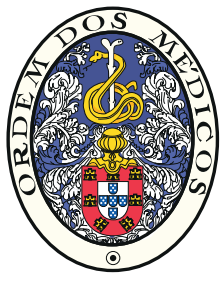

\author{
Mariana NOGUEIRA $\bowtie 1$, Hugo FARIA², Ana VITORINO ${ }^{3}$, Filipe Glória SILVA ${ }^{4}$, Ana SERRÃO NETO1 \\ Acta Med Port 2019 Mar;32(3):183-188 - https://doi.org/10.20344/amp.10985
}

\section{ABSTRACT}

Introduction: The excessive use of video games is an emerging problem that has been studied in the context of addictive behaviors. The aim of this study was to determine the prevalence of use of addictive video games in a group of children and to identify risk factors, protective factors and potential consequences of these behaviors.

Material and Methods: Observational and cross-sectional study of children from the sixth grade using an anonymous questionnaire. Addictive video game use was defined by the presence of 5 out of 9 behavioral items adapted from the DSM- 5 criteria for 'Pathological gambling'. Children who answered 'yes' to 4 items were included in the "Risk group for addictive video game use". We delivered 192 questionnaires and 152 were received and included in the study ( $79.2 \%$ response rate). SPSS statistical software was used.

Results: Half of the participants were male and the median age was 11 years old. Use of addictive video games was present in $3.9 \%$ of children and $33 \%$ fulfilled the risk group criteria. Most children played alone. We found additional factors associated with being in the risk group: greater time of use; online, action and fighting games $(p<0.001)$. Children with risk behaviors showed a shorter sleep duration $(p<0.001)$.

Discussion: A significant number of children of our sample met criteria for addictive video games use in an early age and a greater number may be at risk (33\%). This is a problem that warrants further research and clinical attention.

Conclusion: This exploratory study helps to understand that addiction to video games in children is an emergent problem.

Keywords: Behavior, Addictive; Child; Video Games

\section{RESUMO}

Introdução: O uso excessivo de vídeojogos é um problema emergente que tem vindo a ser estudado no âmbito de comportamentos de dependência. O objetivo deste estudo foi determinar a prevalência de dependência de vídeojogos num grupo de crianças e identificar fatores protetores ou de risco e potenciais consequências deste comportamento.

Material e Métodos: Estudo transversal e observacional de uma população de crianças, do sexto ano escolar, através de um questionário anónimo. A dependência de vídeojogos foi definida como presença de 5 dos 9 comportamentos adaptados dos critérios do DSM-5 de 'pathological gambling'. Crianças com 4 dos 9 critérios foram incluídas no 'Grupo de risco para dependência de vídeojogos'. Foram entregues 192 questionários, com resposta a 152 (taxa de resposta 79,2\%). A análise estatística foi feita com base no SPSS. Resultados: Metade dos participantes eram do sexo masculino, com média de idade 11 anos. A dependência de videojogos esteve presente em 3,9\% da população, sendo que cerca de 33\% da amostra cumpria critérios de 'risco de dependência de videojogos'. A maioria das crianças joga sozinha. Outros fatores de risco encontrados para 'Grupo de risco de dependência' foram mais tempo de uso; tipo de jogo online, ação e luta $(p<0,001)$. Este grupo de crianças apresenta menos tempo de sono.

Discussão: Um número significativo de crianças da nossa amostra cumpre critérios de dependência de videojogos numa idade precoce, e um número maior pode estar em risco desse comportamento (33\%). É um problema clínico emergente, que merece atenção e mais estudos.

Conclusão: Este estudo exploratório sugere que a dependência de videojogos em crianças é um problema emergente.

Palavras-chave: Comportamento Aditivo; Criança; Vídeojogos

\section{INTRODUCTION}

Recent advances in new technologies, internet and video games (VG) have made these activities the top leisure time occupation for children and adolescents. ${ }^{1}$ Although they are very appealing for free time, negative effects of their excessive use have been increasingly recognized. These include sedentarism with increased risk of childhood obesity; sleep disorders related to excessive daytime somnolence; exposure to inappropriate content for age; and psychological addiction to this activity. Various authors have suggested that video games are potentially addictive. ${ }^{1-3}$

To be considered an addictive behavior, it is not enough to take into account the amount of the time spent in this activity, but also the extent of interference in social (family, friendships and relationships), academic or occupational life. ${ }^{4,5}$ Although there is still no consensus or enough studies to establish a definitive diagnosis, the American Psychiatric Association introduced the term 'Internet Gaming Disorder' in the $5^{\text {th }}$ edition of the Diagnostic and Statistical Manual of Mental Disorders (DSM-5), in the section "Conditions for further study".,6,7 In this context, VG addictive behavior may be defined based on four symptoms similar to 'Pathological gambling': loss of control over the activity; decreased

1. Centro da Criança e do Adolescente. CUF Descobertas Hospital. Lisboa. Portugal.

2. Unidade de Medicina do Adolescente. Centro da Criança e do Adolescente. CUF Descobertas Hospital. Lisboa. Portugal.

3. Unidade de Cuidados de Saúde Personalizado da Parede. Agrupamento de Centros de Saúde de Cascais. Lisboa. Portugal.

4. Unidade de Neurodesenvolvimento. Centro da Criança e do Adolescente. CUF Descobertas Hospital. Lisboa. Portugal.

$\square$ Autor correspondente: Mariana Nogueira. mariana.s.nogueira@jmellosaude.pt

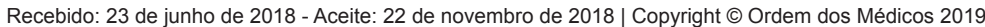


tolerance of use, with progressive increase of activity to achieve satisfaction; negative behavioral effects when it is not possible to continue the activity; and interpersonal and occupational interference. ${ }^{6}$

Although international literature suggests that there are players who experience similar symptoms to other addictive behaviors (pathological gambling, drug addiction), there is no agreement if they truly are players with addictive use. ${ }^{6,8}$ There is still a lack of systematic research concerning not only prevalence rates, but also the definition and nature of problem VG use. $^{9}$

The only data from Portuguese children about the prevalence of VG patterns use is published in a report from the WHO published in $2014 .{ }^{10}$ Besides that, there is currently no validated Portuguese questionnaire to evaluate pathological VG use.

Although we are aware of the variations in cut-off values to diagnose addictive VG use, the primary study aim was to characterize the habits of VG use in a group of children, with mean age of 11 year, and to find the prevalence of addictive VG use in early ages, rather than test a diagnostic instrument. We also tried to identify risk and protective factors of this pattern of behavior.

\section{MATERIAL AND METHODS}

A cross-sectional and observational study was carried out. The target population was $5^{\text {th }}$ or $6^{\text {th }}$ grade students, from different social and cultural backgrounds.

Participants: The sample include $6^{\text {th }}$ grade students from two public schools from the same suburban area (Cascais, near Lisbon). The schools were selected to include participants from a range of economic and cultural backgrounds. Authorization was requested from the Health Delegate, School Director and Education Officers.

Inclusion criteria: Sixth grade students from the selected schools with consent from Education Officers.

Exclusion criteria: All children without Education Officers consent.

We delivered 192 questionnaires and e received 152 (response rate $79.2 \%$ ).

\section{Material}

An anonymous self-administered questionnaire with multiple choice and short-answer questions was applied to a convenience sample of the target population. Initial pretest was performed on a group of 20 children, to gauge the children's acceptance and understanding of the questionnaire.

Questions included: demographic information; 9 items adapted from DSM-5 criteria of addictive gambling use; VG use habits (time of use, places where they play, who they played with); school performance; extra-curricular activities; sleep habits, evaluation of daytime sleepiness; parent's education. Responses were collected between April to June 2016 by pediatric residents.

Gaming frequency was measured in hours per day. Daytime sleepiness was established applying the Pediatric Daytime Sleepiness Scale (PDSS), validated in Portuguese. ${ }^{11}$

\section{Definitions}

Addictive VG use was measured by evaluating the presence of the four symptoms from 'Pathological gambling', based on answers to a short version of adapted items from DSM-5 symptoms/diagnostic criteria. The participants were asked to indicate how often they had experienced each of the situations described in the items within the last year. They were allowed to choose on of three possible answers: 'yes', 'sometimes' and 'no' (Table 1).

We considered the behavior present when there was a 'Yes' answer to at least half of items. We defined addictive VG use by the answers 'Yes' to at least 5 of 9 questionnaire items adapted from the DSM-5.

Due to the high prevalence of children that answered 'Yes' to 4 of the 9 items we felt it important to consider them as a separate group which we termed the 'risk group' for addictive VG use.

Statistical analysis and evaluation of risk and protective

Table 1 - Questions adapted from DSM-5 criteria of addictive gambling use

\begin{tabular}{lll}
\hline Question & Yes No Sometimes \\
\hline
\end{tabular}

1. When you are not playing VG, do you think about it?

2. Over time, do you think that you have been playing more and more hours?

3. Have you ever try to play less, or play shorter periods of time, and you couldn't?

4. When you can not play video games, do you feel upset, restless or angry?

5 . When you are sad, upset or with any problems, do you play video games more?

6 . When you lose or can't pass any level, do you need to play again to try to win?

7. Have you ever play when anyone is watching?

8. To be able to play, do you any one of this things: miss classes, lie, steal, argue with anyone?

9. To spend much time playing, did you ever do any one of this things: skip doing homework, skip meals, sleep later, spend less time with family? 
factors was performed in two steps:

Group 1: Children 'with addictive VG use' versus 'without addictive VG use'.

Group 2: Children 'at risk of addictive VG use' versus without risk (children with 'addictive VG use' were excluded).

The results were analyzed using SPSS (Statistics 19) and $p$ value $<0.05$ was considered statistically significant. Chi-square test, Fisher test and Mann-Whitney test were applied.

\section{RESULTS}

\section{Sample characteristics}

The sample consisted of 152 children. The gender distribution was $72(47 \%)$ female and 80 (53\%) male. The age range of participants was from 10 to 14 years-old, with a mean age of 11.5 years and a median of 11 years. With regards to parents' educational level $24.8 \%$ had basic education (until the $9^{\text {th }}$ Grade), $35.8 \%$ had high school level education and $43 \%$ had a degree level education.

\section{VG global habits of the sample}

Most children ( $n=97 ; 63.8 \%$ ) received their first electronic device between 6 and 10 years of age. However, $3.3 \%(n=5)$ of children claimed to have started playing VG before the age of 4 years old.

When asked about the daily time spent playing VG, most children answered that they play less than 2 hours $(\mathrm{n}=$ 107; 70.8\%). However, 29 (19.2\%) play between 2 - 3 hours and $15(9.9 \%)$ play more than 4 hours during the week. During the weekend, $26(17.1 \%)$ play between 2-3 hours and $37(24.3 \%)$ play more than 4 hours. We found that males tended to play for longer, although without statistical significance.

We found that most children enjoy playing alone $(\mathrm{n}=$ $107 ; 70.9 \%$ ) or with friends $(n=89 ; 58.9 \%)$. The type of favorite VG are: multiplayer online $(n=81,53.6 \%)$, adventure $(n=77 ; 51 \%)$ and action $(n=69 ; 45.7 \%)$. We also verified that the main reasons why they like to play are: to relax $(\mathrm{n}=$ $68 ; 44.7 \%)$, to forget problems $(n=68 ; 44.7 \%)$ and for the challenge of the game $(n=67 ; 44.1 \%)$.

\section{Prevalence of addictive use and identification of pro- tective factors and risk factors \\ 1. Addiction prevalence}

Considering the DSM-5 based criteria, we found that 6 children (3.9\%) fulfilled the 'addictive VG use' criteria (answered at least 5 of 9 questionnaire items). None of the participants answered 'yes' to more than 5 items. On the other hand, we observed a far greater number of our sample (51 children - 33\%) answering 'yes' to 4 of the 9 DSM-5 items. We included them in the group 'at risk for addictive VG use'.

\section{Risk factors}

There were no statistically significant differences between the number of hours playing VG during the week or weekend, and VG addiction. In fact, $93.3 \%$ of children who played more than 4 hours belonged to the group without addictive VG use (Table 2). However, this relationship was statistically significant with the 'risk of addictive VG use' Group $(p<0.001)$ - Table 2.

The results show that multiplayer online games and action/fight games were statistically associated with 'risk of addictive VG use' $(p<0.001)$ - Table 2. This relationship was not statistically significant for children with 'addictive VG use'.

There were no differences in other variables, such as the age of starting to play VG or the time of receiving the first electronic device, between the two groups.

\section{Comorbidities}

Sleep duration was lower in children with 'risk for addictive VG use' (average 8h48, SD 01h07) when comparing to children without these criteria (average 09h17, SD 00h47; $p$ $=0.007$, Mann-Whitney test). Children who play less than 2 hours per day have more sleeping hours $(p<0.001$, MannWhitney test). Regarding PDSS daytime sleepiness score, we found no significant differences between children with and without 'addictive VG use' and between children 'at risk for addictive VG use' and without these criteria (Mann-Whitney tests, respectively, $p=0.068$ and $p=0.120$ ) - Table 2 .

\section{Protective factors}

With regard to parents' educational level we did not find statistically differences between 'addictive VG use' and parents' educational levels.

In this study, we were also unable to identify other protective factors between the two groups of children amongst the studied variables, namely, the existence of a playmate during VG use (parents, siblings, grandparents, friends or others) and extracurricular activities (sports, dance classes, music classes, etc.).

\section{DISCUSSION}

In our study, $29 \%$ of children play VG more than two hours per day during week time and $41 \%$ during the weekend. Besides, $10 \%$ and $25 \%$ of our sample play VG more than 4 hours during the week and the weekend, respectively. Although our population is younger, the numbers are similar to those from the WHO report about VG habits in Portuguese adolescents (about $40 \%$ of adolescents play VG between 1 to 3 hours per day and about $11 \%$ of children play more than four hours during the weekend). ${ }^{10}$ The concern about VG habits among children led to the American Academy of Pediatrics (AAP) providing a new set of recommendations and resources concerning children and adolescents' media use, in order to help parents set a balance in digital activities. ${ }^{12}$ For children aged 6 years and older, the AAP recommended setting consistent limits about the time spent using media, the types of media, and to make sure that it does not take the place of adequate sleep, physical activity and other behaviors essential to good health. ${ }^{12}$

The aim of our exploratory study was to estimate the addictive VG use prevalence in a pediatric Portuguese 
sample. In previous studies, the incidence ranged from $2.5 \%$ to $19.9 \%$. $^{1-3,13,14}$ More recent data shows lower percentages of players who can be labelled as probably addicted $(0.2 \%-2 \%)$, and describes others as problematic users $(3.7 \%-9 \%)$, depending on methodological issues and the cut-off for 'addiction' or 'problematic' use. ${ }^{8,9,15}$ Some authors defend that 5 out of 9 criteria should classify players just as 'problematic' rather than addictive players. ${ }^{8,9}$ In our study, we defined addictive VG use with the cut-off of 5 item, which represents the minimum number of symptoms necessary to classify an addiction pattern based on 'gambling addiction' DSM-5 criteria. Considering this, $3.9 \%$ of our sample would be classified as having an addictive VG use.

Although we must be cautious concerning labelling behavior as abnormal, we found important to show that a greater population may be at 'risk of addictive VG use', since almost one third of our sample had 'borderline' criteria answering 'yes' to 4 items. However, as Scharkow et al de- scribed, longitudinal studies are needed in order to confirm this finding and to understand the trajectories of these children along the years. In fact, they suggested that problematic gaming is highly volatile. ${ }^{9}$

It has been observed that behavioral changes can start at early ages. ${ }^{3,13} \mathrm{Ko}$ et al, Johansson et al, and Johansson \& Gotestam found prevalence of addictive use in children as soon as 15-years old, and Douglas Gentile et al since 8 -years-old. , $^{1,3}$ We felt it important to study this age range to get data from Portuguese children.

Several game types and personal characteristics seem to act as risk factors. ${ }^{1,13,16,17}$ Although we did not find a relationship between addiction and the amount of time spent playing, this may be due to the small number of children with these criteria. In fact, we identified that time of VG use seems to contribute to being at 'risk of addictive VG use'. Other authors justify the frequent playing as a result from simply healthy enthusiasm. ${ }^{8}$ In the same way, multiplayer

Table 2 - Risk factors for addictive VG use

\begin{tabular}{|c|c|c|c|c|c|c|}
\hline & \multicolumn{3}{|c|}{ GROUP 1} & \multicolumn{3}{|c|}{ GROUP 2} \\
\hline & $\begin{array}{c}\text { Without additive } \\
\text { use criteria, } \\
\text { n (\%) }\end{array}$ & $\begin{array}{c}\text { With additive } \\
\text { use criteria, } \\
\text { n (\%) }\end{array}$ & $p$ value & $\begin{array}{l}\text { Without risk } \\
\text { behaviour, } \\
\text { n (\%) }\end{array}$ & $\begin{array}{l}\text { With risk } \\
\text { behaviour, } \\
\mathrm{n}(\%)\end{array}$ & $p$ value \\
\hline \multicolumn{7}{|c|}{ How much hours do children play during the week } \\
\hline $00: 00 \mathrm{~h}$ & $22(95.7)$ & $1(4.3)$ & \multirow{6}{*}{$0.06^{2}$} & $20(87.0)$ & $3(13.0)$ & \multirow{6}{*}{$<0.001$} \\
\hline $00: 00-00: 30 h$ & $42(100.9)$ & $0(0.0)$ & & $35(83.3)$ & $7(16.7)$ & \\
\hline $00: 30-01: 59 h$ & $41(97.6)$ & $1(2.4)$ & & $33(78.6)$ & $9(21.4)$ & \\
\hline $02: 00-03: 59 h$ & $26(89.7)$ & $3(10.3)$ & & $9(31.0)$ & $20(69.0)$ & \\
\hline$>04: 00 \mathrm{~h}$ & $14(93.3)$ & $1(6.7)$ & & $4(26.7)$ & $11(73.3)$ & \\
\hline Total & $145(96.0)$ & $6(4.0)$ & & $101(66.9)$ & $50(33.1)$ & \\
\hline \multicolumn{7}{|c|}{ How much hours do children play during the weekend } \\
\hline $00: 00 \mathrm{~h}$ & $9(90.0)$ & $1(10.0)$ & \multirow{6}{*}{$0.082^{2}$} & $9(90.0)$ & $1(10.0)$ & \multirow{6}{*}{$<0.001^{1}$} \\
\hline $00: 00-00: 30 h$ & $34(100.0)$ & $0(0.0)$ & & $28(82.4)$ & $6(17.6)$ & \\
\hline $00: 30-01: 59 h$ & $45(100.0)$ & $0(0.0)$ & & $34(75.6)$ & $11(24.4)$ & \\
\hline $02: 00-03: 59 h$ & $26(100.0)$ & $0(0.0)$ & & $15(57.7)$ & $11(42.3)$ & \\
\hline$>04: 00 \mathrm{~h}$ & $32(86.5)$ & $5(13.5)$ & & $15(40.5)$ & $22(59.5)$ & \\
\hline Total & $146(96.1)$ & $6(3.9)$ & & $101(66.4)$ & $51(33.6)$ & \\
\hline \multicolumn{7}{|c|}{ Age in which they began to play } \\
\hline$<4$ years & $5(100.0)$ & $0(0.0)$ & \multirow{6}{*}{$\mathrm{NA}^{3}$} & $2(40.0)$ & $3(60.0)$ & \multirow{6}{*}{$\mathrm{NA}^{1}$} \\
\hline $4-5$ years & $25(96.2)$ & $1(3.8)$ & & $14(53.8)$ & $12(46.2)$ & \\
\hline $6-8$ years & $56(93.3)$ & $4(6.7)$ & & $43(71.1)$ & $17(28.3)$ & \\
\hline $8-9$ years & $47(97.9)$ & $1(2.1)$ & & $33(68.8)$ & $15(31.3)$ & \\
\hline $10-12$ years & $13(100.0)$ & $0(0.0)$ & & $9(69.2)$ & $4(30.8$ & \\
\hline Total & $146(96.1)$ & $6(3.9)$ & & $101(66.4)$ & $51(33.6)$ & \\
\hline \multicolumn{7}{|c|}{ Age in which they had the first electronic device } \\
\hline$<4$ years & $5(100.0)$ & $0(0.0)$ & \multirow{6}{*}{$\mathrm{NA}^{3}$} & $3(60.0)$ & $2(40.0)$ & \multirow{6}{*}{$\mathrm{NA}^{1}$} \\
\hline $4-5$ years & $5(83.3)$ & $3(16.7)$ & & $9(500)$ & $9(50.0)$ & \\
\hline $6-8$ years & $44(100.0)$ & $0(0.0)$ & & $287(61.4)$ & $17(38.6)$ & \\
\hline $8-9$ years & $51(96.2)$ & $2(3.8)$ & & $37(69.8)$ & $16(21.9)$ & \\
\hline $10-12$ years & $31(96.9)$ & $1(3.1)$ & & $25(78.1)$ & 7 (21.9) & \\
\hline Total & $146(96.1)$ & $6(3.9)$ & & $101(66.4)$ & $51(33.6)$ & \\
\hline
\end{tabular}


Table 2 - Risk factors for addictive VG use

\begin{tabular}{|c|c|c|c|c|c|c|}
\hline & \multicolumn{3}{|c|}{ GROUP 1} & \multicolumn{3}{|c|}{ GROUP 2} \\
\hline & $\begin{array}{c}\text { Without additive } \\
\text { use criteria, } \\
\text { n (\%) }\end{array}$ & $\begin{array}{l}\text { With additive } \\
\text { use criteria, } \\
\text { n (\%) }\end{array}$ & $p$ value & $\begin{array}{c}\text { Without risk } \\
\text { behaviour, } \\
\text { n (\%) }\end{array}$ & $\begin{array}{c}\text { With risk } \\
\text { behaviour, } \\
\text { n (\%) }\end{array}$ & $p$ value \\
\hline \multicolumn{7}{|c|}{ Type of games } \\
\hline \multicolumn{7}{|c|}{ Action } \\
\hline No & $81(98.8)$ & $1(1.2)$ & \multirow{3}{*}{$0.093^{2}$} & $60(73.2)$ & $22(26.8)$ & \multirow{3}{*}{$0.049^{1}$} \\
\hline Yes & $64(92.8)$ & $5(7.2)$ & & $40(58.0)$ & $29(42.0)$ & \\
\hline Total & $145(96.0)$ & $6(4.0)$ & & $100(66.2)$ & $51(33.8)$ & \\
\hline \multicolumn{7}{|c|}{ Adventure } \\
\hline No & 71 (95.9) & $23(4.1)$ & \multirow{3}{*}{$>0.999^{2}$} & $53(71.6)$ & $21(28.4)$ & \multirow{3}{*}{$0.169^{1}$} \\
\hline Yes & $74(96.1)$ & $3(3.9)$ & & $47(61.0)$ & $30(39.0)$ & \\
\hline Total & $145(96.0)$ & $6(4.0)$ & & $100(66.2)$ & $51(33.8)$ & \\
\hline \multicolumn{7}{|l|}{ Fight } \\
\hline No & $100(97.1)$ & $3(29.0)$ & \multirow{3}{*}{$0.383^{2}$} & 76 (73.8) & $27(16.2)$ & \multirow{3}{*}{$0.004^{1}$} \\
\hline Yes & 45 (93.8) & $3(6.3)$ & & $24(50.0)$ & $24(50.0)$ & \\
\hline Total & $145(96.0)$ & $6(4.0)$ & & $100(66.2)$ & $51(33.8)$ & \\
\hline \multicolumn{7}{|l|}{ Run } \\
\hline No & $97(97.0)$ & $3(3.0)$ & \multirow{3}{*}{$0.406^{2}$} & $68(68.0)$ & $32(32.0)$ & \multirow{3}{*}{$0.518^{1}$} \\
\hline Yes & $48(94.1)$ & $3(5.9)$ & & $32(62.7)$ & $19(37.3)$ & \\
\hline Total & $145(96.0)$ & $6(4.0)$ & & $100(66.2)$ & $51(33.8)$ & \\
\hline \multicolumn{7}{|c|}{ Strategy } \\
\hline No & $95(96.0)$ & $4(4.0)$ & \multirow{3}{*}{$>0.999^{2}$} & $66(66.7)$ & $33(33.3)$ & \multirow{3}{*}{$0.874^{1}$} \\
\hline Yes & $50(96.2)$ & $2(3.8)$ & & $34(65.4)$ & $18(34.6)$ & \\
\hline Total & $145(96.0)$ & $6(4.0)$ & & $100(66.2)$ & $51(33.8)$ & \\
\hline \multicolumn{7}{|c|}{ Sport } \\
\hline No & 92 (97.9) & $2(2.1)$ & \multirow{3}{*}{$0.197^{2}$} & $67(71.3)$ & $27(28.7)$ & \multirow{3}{*}{$0.077^{1}$} \\
\hline Yes & $52(92.9)$ & $4(7.1)$ & & $32(57.1)$ & $24(42.9)$ & \\
\hline Total & $144(96.0)$ & $6(4.0)$ & & $99(66.0)$ & $51(34.0)$ & \\
\hline \multicolumn{7}{|c|}{ Logic reasoning } \\
\hline No & $126(96.9)$ & $4(3.1)$ & \multirow{3}{*}{$0.196^{2}$} & $85(65.4)$ & $45(34.6)$ & \multirow{3}{*}{$0.587^{1}$} \\
\hline Yes & $19(90.5)$ & $2(9.5)$ & & $15(71.4)$ & $6(28.6)$ & \\
\hline Total & $145(96.0)$ & $6(4.0)$ & & $100(66.2)$ & $51(33.8)$ & \\
\hline \multicolumn{7}{|c|}{ Online games (multiplayer) } \\
\hline No & $68(97.1)$ & $2(2.9)$ & \multirow{3}{*}{$0.686^{2}$} & $55(78.6)$ & $15(21.4)$ & \multirow{3}{*}{$0.003^{1}$} \\
\hline Yes & $77(95.1)$ & $4(4.9)$ & & $45(55.6)$ & $36(44.4)$ & \\
\hline Total & $145(96.0)$ & $6(4.0)$ & & $100(66.2)$ & $51(33.8)$ & \\
\hline
\end{tabular}

online, action and fighting game types, which are the favorite VG of our sample, were associated with this group. Other authors have demonstrated the importance of game type and content, ${ }^{3,12}$ as violent games have been shown to have short and long-term effects on behavior, such as aggressive behaviors becoming more frequent. ${ }^{1,4,5}$ There was no relation with the age when children started to play video games and addictive use but, as we mentioned, longitudinal studies are needed.

In our sample, parental educational level did not influence the patterns of VG use. This can be justified by the current lifestyle in which a large number of children use mo- bile phones and computers, even in economically disadvantaged families. ${ }^{12}$ On the other hand, a high socioeconomic level does not necessarily mean greater awareness of their risks and readiness to take actions in order to prevent or control excessive VG use. Another reason may be related to the life and parenting style that allows children to spend more time unsupervised, and more susceptible to VG overuse.

Unfortunately, our study was unable to identify protective factors that could help preventing addictive VG use. A different study design is needed, including variables about parent educational styles/social support and both parental 
and child mental health.

With regard to other possible consequences of VG use, we found that children 'at risk of VG addiction' slept for significantly fewer hours. Non-significant results for the "addictive VG use" group and for the PDSS somnolence scores may be due to the small sample size of the study groups. The relation between VG use and sleep is relevant as sleep may impact learning, emotional regulation and behavior. ${ }^{18,19}$ In the present exploratory approach, we used a convenience sample that may not fully represent the target population. However, we found our sample with a significant number of children, from different social and cultural status, which may help to highlight this emergent problem. The behavioral evaluation was performed using a self-reported questionnaire that was not previously subjected to clinical validation. Nevertheless, this questionnaire has the strength of being based on the DSM-5 proposed criteria and the pretest showed that it was easy to fill out, allowing a good response rate. In future studies, child psychological assessment should be also included in order to clarify the link between VG use and emotional problems.

\section{CONCLUSION}

This exploratory study helps to understand that VG addiction in youth is an emergent problem. However, because of smaller incidence than reported by other authors, our results may indicate a far less stable condition that in previous studies. This process of addiction is possible to change and both parents and children need to be educated about the risks and impact of these behaviors and to develop a healthier lifestyle and leisure habits. Further research is needed in order to clarify whether these characteristics represent a 'gaming disorder' or 'gaming addiction'. 15,20

\section{ACKNOWLEDGMENTS}

\section{Merlin McMillan.}

\section{PROTECTION OF HUMANS AND ANIMALS}

The authors declare that the procedures were followed according to the regulations established by the Clinical Research and Ethics Committee and to the Helsinki Declaration of the World Medical Association.

\section{DATA CONFIDENTIALITY}

The authors declare having followed the protocols in use at their working center regarding patients' data publication.

\section{CONFLICTS OF INTEREST}

All authors report no conflict of interest.

\section{FUNDING SOURCES}

This research received no specific grant from any funding agency in the public, commercial, or not-for-profit sectors.

\section{REFERENCES}

1. Nabruco de Abreu C, Karam RG, Góes DS, Spritzer DT. Dependência de internet e jogos eletrónicos: uma revisão. Rev Bras Psiquiatr. 2008;30:156-67

2. Tejeiro Salguero RA, Bersabé Morán RM. Measuring problem video game playing in adolescents.. Addiction, 2002;97:1601-6.

3. Gentile D. Pathological vídeo-game use among youth ages 8 to 18 . A national study. Psychol Sci. 2009;20:594-602.

4. Gentile DA, Choo H, Liau A, Sim T, Li D, Fung D, et al. Pathological vídeo game use among youths: a two-year longitudinal study. Pediatrics. 2011;127: 319-29.

5. Weinstein AM. Computer and video game addiction - a comparison between game users and non-game users. Am J Drug Alcohol Abuse. 2010:268-76.

6. Arlington VA. American Psychiatric Association: Diagnostic and Statistical Manual of Mental Disorders, Fifth Edition. American Psychiatric Association, 2013. [Internet site]. [consulted 2018 jun 20]. Available from: https://dsm.psychiatryonline.org/doi/book/10.1176/appi. books.9780890425596.

7. Rooij AJ, Schoenmakers TM, Eijnden SR, Vermulst AA, Mheen DV. Video game addiction test: validity and psychometric characteristics. Cyberpsychol Behav Soc Netw. 2012, 15:507-11.

8. Festl R, Scharkow M, Quandt T. Problematic computer game use among adolescents, younger and older adults. Addiction. 2013;108:592-9.

9. Scharkow M, Festl R, Quandt T. Longitudinal patterns of problematic computer game use among adolescents and adults - a 2-year panel study. Addiction. 2014;109:1910-17.

10. Simões M, Camacho I, Reis M, Aventura social. The health of Portuguese teens in times of recession. Health Behaviour in School-aged Children (HBSC). Geneva: WHO; 2015.

11. Moreno T. Estudo da sonolência diurna e hábitos de sono numa população escolar dos 11-15 anos - Validação em português da "Pediatric Daytime Sleepiness Scale". Lisboa: FMUL; 2012.

12. American Academy of Pediatrics. Media Use in School-Aged Children and Adolescents. 2016. [online]. [consulted 2018 Jun 20]. Available from: http://pediatrics.aappublications.org/content/138/5/e20162592.

13. Johansson A, Götestam KG. Internet addiction: characteristics of a questionnaire and prevalence in Norwegian youth (12-18 years). Scand J Psychol. 2004;45:223-9.

14. Liu TC, Desai RA, Krishnan-Sarin S, Cavallo DA, Potenza MN Problematic Internet use and health in adolescents: data from a high school survey in Connecticut. J Clin Psychiatry. 2011;72:836-45.

15. Griffiths MD, Van Rooij AJ, Kardefelt-winther D, Starcevic V, Király O, Pallesen S, et al. Working towards an international consensus on criteria for assessing internet gaming disorder: a critical commentary on Petry et al. Addiction, 2016,111:167-75.

16. O uso de videogames, jogos computador e internet por uma amostra de universitários da universidade de S. Paulo. J Bras Psiquiatr 2009;58:162-8.

17. Porter G, Starcevic V, Berle D, Fenech P. Recognizing problem video game use. Aust N Z J Psychiatry. 2010,44:120-8.

18. Abreu CN, KaramII RG, Góes DS, Spritzer DT. Internet and videogame addiction: a review. Rev Bras Psiquiatr. 2008,30:156-67.

19. Beebe DW. Cognitive, behavioral and functional consequences of inadequate sleep in children and adolescents: Pediatr Clin North Am. 2011,58:649-65.

20. Gentile AD, Bailey K, Bavelier D, Brockmyer JF, Cash H, Coyne SM, et al. Internet gaming disorder in children and adolescents. Pediatrics. 2017;140:S81-5. 